\title{
VITAMIN D DEFICIENCY- CURRENT STATUS AND ITS IMPACT IN CLINICAL MEDICINE
}

\section{From the desk of Editorial board}

It has been estimated that one billion cases of Vitamin D Deficiency or Insufficiency is present worldwide. In several studies, 40 to $100 \%$ of U.S. and European elderly men and women are vitamin D deficient ${ }^{1}$. More than $50 \%$ of postmenopausal women taking $\mathrm{rx}$ for osteoporosis are vitamin $\mathrm{D}$ deficient wile $45 / 80$ (56.2\%) of geriatric patients in a UCDSOM study of vit. D education intervention study were vitamin D deficient.Vitamin D Levels in the LUCHAR Dataset showed 34/139 (24.5\%) normal, 40/139 (28.8\%) insufficiency, 65/139 (46.8\%) deficiency [Mean 22.5 $\mathrm{ng} / \mathrm{mL}$ with Range $<5-52 \mathrm{ng} / \mathrm{mL}$ ]

In Northern China where $42 \%$ of infants were found to suffer from hypovitaminosis during the winter/ spring period, $89 \%$ of them are Chinese adolescent girls and $48 \%$ of old men had severe deficiency ${ }^{2}$.Among postmenopausal women serum $25(\mathrm{OH}) \mathrm{D}$ level lower amongst the Malays $(44 \pm 11 \mathrm{nmol} /$ L) than the Chinese $(69 \pm 16 \mathrm{nmol} / \mathrm{L})^{2}$

In SEA, $80 \%$ of the apparently healthy population is deficient in vitamin $\mathrm{D}(<20 \mathrm{ng} / \mathrm{mL})$ and up to $40 \%$ of the population is severely deficient $(<9 \mathrm{ng} / \mathrm{mL})$ 3 .Prevalence of hypovitaminosis D $(25(\mathrm{OH}) \mathrm{D}$ $<75 \mathrm{nmol} / \mathrm{L}$ ) in postmenopausal women in $47 \%$ in Thailand, 49\% in Malaysia, 90\% in Japan , 92\% in South Korea. The mean serum 25(OH)D concentration was $48 \mathrm{nmol} / \mathrm{L}$ in premenopausal women from Indonesia $\left(6^{\circ} \mathrm{S}\right)$ and Malaysia $\left(2^{\circ} \mathrm{N}\right)$

In Pakistan, the median level of serum vitamin $D$ was 18.8 (IQ range 12.65-24.62) ng/dL. A total of 253 $(84.3 \%)$ respondents had low levels (30ng/dL) of $25 \mathrm{OH}$ vitamin D.In Karachi, $55 \%$ of infants and $45 \%$ of mothers had very low serum 25(OH)D levels $(<25$ $\mathrm{nmol} / \mathrm{L}$ or $10 \mathrm{ng} / \mathrm{mL})^{4}$

In North India $\left(27^{\circ} \mathrm{N}\right)$, Hypovitaminosis $\mathrm{D}$ was found in $96 \%$ of neonates , $91 \%$ of healthy school girls , $78 \%$ of healthy hospital staff and $84 \%$ of pregnant women .() In South India $\left(13^{\circ} \mathrm{N}\right)$ hypovitaminosis D was associated with inverse relationship between measured serum 25(OH)D levels and PTH levels and Vitamin D levels were significantly higher in rural compared to urban subjects. In Lucknow,India it was found that $84 \% \mathrm{t}$ of pregnant women had $25(\mathrm{OH}) \mathrm{D}$ values below $22 \mathrm{ng} / \mathrm{mL}^{5,6}$

In Sri Lanka $\left(7^{\circ} \mathrm{N}\right)$, mean $25(\mathrm{OH}) \mathrm{D}$ among healthy females was $35.3 \mathrm{nmol} / \mathrm{L}, 40.5 \%$ of them had $25(\mathrm{OH}) \mathrm{D}$ values below $25 \mathrm{nmol} / \mathrm{L}$. High prevalence's was found in Skin hyperpigmentation, traditional clothing, air pollution, limited outdoor activity and urban population. ${ }^{7}$

In Bangladesh $\left(24^{\circ} \mathrm{N}\right)$ hypovitaminosis $\mathrm{D}$ was found in women regardless of age, lifestyle and clothing and 25(OH)D levels below $37.5 \mathrm{nmol} / \mathrm{L}$ was observed in $38 \%$ from high income group and $50 \%$ in women from low income groups. ${ }^{8}$ Vitamin D deficiency (serum 25-OHD level $<25 \mathrm{nmol} / 1$ ) was detected in $39 \%$ of young women (university students), 30\% in veiled women and $38 \%$ in diabetic women, respectively. 9,10 Though the rural students are less familiar with vitamin $\mathrm{D}(\mathrm{p}<0.001)$ and osteoporosis $(\mathrm{p}=0.0056)$ than urban students, they exercise a healthy diet in terms of milk consumption $(p<0.0001)$ and engage themselves more in outdoor activities. They spend more time in sunlight $(p<0.0001)$ than the urban students and thus the rural students may require less supplemental support of calcium and/or vitamin $\mathrm{D}$ than the urban students $(\mathrm{p}<0.0001) .{ }^{11}$ In another study between man versus woman, $50 \%$ of the men but only $23 \%$ of women spent e" 2 hours outdoors per day during daytime hours ( $\mathrm{n}=82, \mathrm{p}=0.0007) .24 \%$ of men and $0 \%$ of women reported outdoor professions $(\mathrm{p}<0.0001)$.Men's mean 25(OH)D $(55.2 \pm 17.5 \mathrm{nmol} / \mathrm{L})$ was significantly higher than women's $(21.6$ $\pm 10.7 \mathrm{nmol} / \mathrm{L}$ ) (mean difference $=30.7 \mathrm{nmol} / \mathrm{L}$; $\mathrm{p}<0.0001)$.A significantly lower proportion of men $(6.0 \%)$ were vitamin $\mathrm{D}$ deficient $(25(\mathrm{OH}) \mathrm{D}<30 \mathrm{nmol} / \mathrm{L})$ vs women $(21.7 \% ; \mathrm{p}<0.0001)^{12}$. A study on socioeconomic groups [ low( L) versus high $(\mathrm{H})$ ] Seventeen percent of women in group $\mathrm{L}$ and $12 \%$ of women in group $\mathrm{H}$ had serum 25-OHD concentration $<25 \mathrm{nmol} / 1$. Hypovitaminosis D (serum 25-OHD concentration $37.5 \mathrm{nmol} / 1$ ) was observed in $50 \%$ of subjects in group L and $38 \%$ of subjects in group $\mathrm{H}$, respectively.The prevalence of hypovitaminosis was

Bangladesh J Medicine 2017; 28: 1-3 
higher in lactating subjects of the groups L and $\mathrm{H}$ (63 and $46 \%$, respectively) ${ }^{13}$.In a study in $\mathrm{DMCH}$ in preeclmpsia and eclampsia The prevalence of vitamin D insufficiency was very high with more than 3 quarters $(78 \%)$ of all subjects having a serum $25(\mathrm{OH}) \mathrm{D}$ level < $30 \mathrm{ng} / \mathrm{ml}$. The mean serum 25(OH)D level was $24.86 \mathrm{ng} / \mathrm{ml}$ in controls, $23.96 \mathrm{ng} / \mathrm{ml}$ in pre eclamptic women, and $21.56 \mathrm{ng} / \mathrm{ml}$ in eclampsia patients. The odds of developing preeclampsia and eclampsia may increase by up to 5 -fold in women with vitamin $\mathrm{D}$ insufficiency. ${ }^{14}$ A thesis by Zannatul Mawa, showed students who are studying college do not have adequate knowledge of essential nutrients, minerals, vitamins etc. College students have a long academic background related to general biological science. If they have gap of knowledge about calcium and vitamin $\mathrm{D}$, the general people may know little about these food supplements

Sources of Vitamin D are Exposure to sunlight, dietary sources and dietary supplements. 5-10 minutes of direct exposure to the arms and legs , 3000 IU of vitamin D3.In a study in Boston, 36\% had $25 \mathrm{OH}$ vit $\mathrm{D}$ level $<20 \mathrm{ng} / \mathrm{ml}$ at the end of winter. The prevalence decreased to $4 \%$ by the end of summer. ${ }^{1}$ Multiple studies show vitamin D def. common in sunny areas when most of the skin is shielded from the sun (Saudi Arabia, United Arab Emirates, Turkey, India and Lebanon)

1,25 OH Vitamin D Effects are increased calcium absorption in the gut,increased PTH mediated bone resorption, decreased renal calcium and phosphorus excretion, decreased PTH secretion and increased bone calcification. PTH Effects are characterized by Increases tubular reabsorption of calcium, stimulates the kidney to produce $1,25 \mathrm{OH}$ vitamin $\mathrm{D}$, activates osteoblasts, which then stimulates the activation of osteoclasts, osteopenia and osteoporosis and increasing the risk of fracture. It also causes phosphaturia. A low Ca-Phos product leads to decreased mineralization of the collagen matrix leading to rickets in kids and osteomalacia in adults.

Non-classical Actions of Vitamin D are suppression of cell growth/proliferation, regulate apoptosis, modulate immune responses, susceptibility to infections, susceptibility to autoimmune disorders like Multiple Sskerosis, T1DM and effects in transplantation immunity. It also modulate keratinocyte differentiation and function and play key role in psoriasis therapy. Vit D suppress reninangiotensin system, stimulate insulin secretion an control neuromuscular function and the brain. ${ }^{15}$

Mechanisms of Vitamin D Deficiency based on reduced skin synthesis by means of use of sunscreen (SPF 15 reduces D3 by 99\%), skin pigmentation, aging (reduction of 7 dehydrocholesterol reduces vitamin D3 by $75 \%$ ), season, latitude and time of day and also patients with skin grafts for burns. Inadequate dietary intake, malabsorptive disorders and obesity, impaired hydroxylation by the liver due to liver disease, increased hepatic catabolism due to medications, impaired renal production of $1,25-\mathrm{OH}$ vit. $\mathrm{D}$ in stage 4 and $5 \mathrm{CKD}$, renal loss of vit. D and vit. $\mathrm{D}$ binding proteins in nephrotic syndrome are also responsible factors for Vit D deficinecy

A meta-analysis of 7 RCT's evaluating fracture risk in pts given 400 IU of vit D3 per day revealed little benefit. ${ }^{16}$ In studies using 700-800 IU of of vitamin D3 per day, the RR of hip fracture and nonvertebral fracture were reduced by $26 \%$ and $23 \%$ respectively compared to calcium and placebo. ${ }^{16}$ Skeletal muscle has a vitamin D receptor for maximal function. A meta-analysis of $5 \mathrm{RCT}$ with 1237 subject showed increased vitamin D reduced the risk of falls by $22 \%$. It was found that $400 \mathrm{IU}$ of vitamin $\mathrm{D}$ per day was not as effective $800 \mathrm{IU}$ vitamin D per day for reduction of fracture and fall.

In a study of hypertensive patients who were exposed to ultraviolet $\mathrm{B}$ radiation three times per week for 3 months. $25 \mathrm{OH}$ vitamin D levels increased by approximately $180 \%$ and both SBP and DBP were reduced by $6 \mathrm{~mm} \mathrm{Hg}$. In 10,366 children in Finland, 2000 IU of vitamin D3 per day (1st yr) \& follow up the risk of Diabetes Mellitus was reduced by $80 \%$. In subset analysis, among children with vitamin D deficiency, the risk was increased by $200 \%$.Combined $1200 \mathrm{mg}$ of calcium +800 IU of vitamin D lowered the risk by $33 \%$ compared to $<600 \mathrm{mg}$ calcium $+<400 \mathrm{IU}$ of vitamin D.

Vitamin D levels of $40 \mathrm{ng} / \mathrm{ml}$ or higher may confer some protection against Multiple Sclerosis. Patients receiving Magnesium, Calcium and 5000 IU vitamin D significantly reduced MS exacerbations (14 vs 32). Vitamin D may be primarily associated with cognitive domains other than memory, such as executive cognitive functions, depression, bipolar disorders, and schizophrenia. Low $25(\mathrm{OH}) \mathrm{D}$ may be a risk factor for cognitive impairment (41-60\%). Increased Vitamin D may improve cognitive function in patients with Alzheimer's disease. $25 \mathrm{OH}$ vitamin D below $20 \mathrm{ng} /$ $\mathrm{ml}$ are associated with $30-50 \%$ increased risk of incident and mortality of colon, prostate and breast cancer. D 1-alpha hydroxylase and 1,25 $\mathrm{OH}$ vitamin $\mathrm{D}$ act locally to control genes that prevent cancer by limiting cellular proliferation and differentiation by inhibiting angiogenesis and inducing apoptosis. 
Among 13,331 adults 20 years or older from NHANES III testing association of low $25 \mathrm{OH}$ vitamin $\mathrm{D}$ and all cause, cancer and cardiovascular mortality, it was found 1806 deaths, including 777 from CVD. In multivariate models $(25 \mathrm{OH}$ vitamin $\mathrm{D}<17.8 \mathrm{ng} / \mathrm{ml}$ ) was associated with a $26 \%$ increased rate of all cause mortality, (95\% CI, 1.08-1.46.) ${ }^{17}$

So it can be deduced that Vitamin D deficiency is common. $25 \mathrm{OH}$ vitamin $\mathrm{D}$ is a predictor of bone health in terms of fracture risk and risk of falls and $25 \mathrm{OH}$ vitamin $\mathrm{D}$ is also an independent predictor of risk of cardiovascular disease, hypertension, cancer, diabetes, all cause mortality, and URTI. Sensible sun exposure is a great way to maintain vitamin D sufficiency and we must encourage the risk and vulnerable group to enjoy the natural source of vitamin D. The sun vitamin is more important for countries like Bangladesh who are in a threat of vitamin $\mathrm{D}$ deficient era.

\section{Quazi Tarikul Islam', Md Robed Amin ${ }^{\mathbf{2}}$}

${ }^{1}$ Professor of Medicine, Popular Medical College,

${ }^{2}$ Assoc Prof of Medicine, Dhaka Medical College,

\section{References:}

1. Holick et al. J Clin Endocrinol Metab 2005, Vitamin D Deficiency. N Engl J Med 2007; 357: 266-8-21

2. Arya V, Bhambri R, Godbole MM, Mithal A.Vitamin $\mathrm{D}$ tatus and its relationship with bone mineral density in healthy Asian Indians. Osteoporsis Int 2004; 15(1): 56- 61 .

3. Nazmul ahasan,Aparna das, editorial, Journal of Enam Medical College Vol 3 No 2 July 2013

4. Adil Sheikh1, Zeb Saeed1, Syed Ali Danial Jafri2, Iffat Yazdani2, Syed Ather Hussain2*Vitamin D Levels in Asymptomatic Adults-A Population Survey in Karachi, Pakistan. PLoS ONE | www.plosone.org 1 March 2012 | Volume 7 | Issue 3 | e33452

5. Sachan A, Gupta R, Das V, et al. (2005) High prevalence of vitamin $\mathrm{D}$ deficiency among pregnant women and their newborns in northern India. Am J Clin Nutr 81:1060-1064.

6. Puri S, Marwaha RK, Agarwal N, et al. (2008) Vitamin D status of apparently healthy schoolgirls from two different socioeconomic strata in Delhi: relation to nutrition and lifestyle. Br J Nutr 99:876882.

7. Rodrigo MD (2007) Peak bone mass measured by phalangeal BMD and its association with nutritional status, socioeconomics status and physical activity: a community based cross sectional study in Galle district, Sri Lanka. In. Extract from PHD thesis (unpublished).

8. 1sam MZ, Akhtaruzzaman M, Lamberg-Allardt C (2006) Hypovitaminosis D is common in both veiled and nonveiled Bangladeshi women. Asia Pac J Clin Nutr 15:81-87.

9. Islam $\mathrm{MZ}$, Lamberg-Allardt $\mathrm{C}$, Karkkainen $\mathrm{M}$, et al. (2002) Vitamin D deficiency: a concern in premenopausal Bangladeshi women of two socioeconomic groups in rural and urban region. Eur $\mathrm{J}$ Clin Nutr 56:51-56.

10. Md Zahirul Islam PhD1, Mohammed Akhtaruzzaman PhD2 and Christel Lamberg-Allardt PhD, Hypovitaminosis D is common in both veiled and nonveiled Bangladeshi women. Asia Pac J Clin Nutr 2006; 15 (1): 81-87

11. Dewan Taslima Akhter, Riaz Uddin, Dilshad Yasmin ,Rajia Sultana Nijhu. Calcium and Vitamin D Related Knowledge in 16-18 Years Old Adolescents: Does Living in Urban or Rural Arsea Matter J Nutr Food Sci Volume $3 \cdot$ Issue $6 \cdot 1000240$

12. Joy Shi, Eszter Papp, Abdullah Al Mahmud, Alison Gernand, Aniel Roth Lindsay Ruiter, Vitamin D Status of Husbands of Pregnant Women in Dhaka, Bangladesh .JHPN,Vol 10:11-16

13. $\mathrm{MZ}$ Islam, C Lamberg-Allardt, $\mathrm{M}$ Ka"rkka“inen, $\mathrm{T}$ Outila, Q Salamatullah and AA Shamim.Vitamin D deficiency: a concern in premenopausal Bangladeshi women of two socio-economic groups in rural and urban region. European Journal of Clinical Nutrition (2002) 56, 51-56

14. M. I. Ullah 1, C. A. Koch 1,2 , S. Tamanna 2 , S. Rouf 3 , L. Shamsuddin 4,Vitamin D Defi ciency and the Risk of Preeclampsia and Eclampsia in Bangladesh.Hormone and Metabolic Research · June 2013

15. Dusso AS, et al. Non classical action of vitamin D. Am J Physiol-Renal Physiol 2005;289:F8-F28.

16. Bischoff-Ferrari, H. A et al. Fracture risk and vitamin D. Am J Clin Nutr 2006;84:18-28

17. Melamed, M. L. et al. All cause of mortality and vitamin D. Arch Intern Med 2008;168:1629-1637. 